\title{
A Question of Identity in the Life and Works of Sat-Okh (Long Feather)
}

\author{
Zagadnienie tożsamości w życiu i twórczości Sat-Okha
}

Milena LESZMAN ${ }^{1}$

Ateneum-Szkoła Wyższa w Gdańsku

\begin{abstract}
Sat-Okh (Stanisław Supłatowicz) was an Indian-Polish writer who popularised the culture of North American Indigenous People in Poland during the Cold War and afterwards. His incredible biography evokes questions about the nature of his identity. Born of an Indian chief and a Polish mother around 1922 in the territory of Alberta, Sat-Okh grew up as a Shawnee. When his mother decided to return to Poland, he followed, but until his death in Gdańsk in 2003, Sat-Okh consistently identified with his Indigenous heritage. During WWII he escaped from a train to Auschwitz and joined the AK (The Home Army). He became famous for numerous books and short stories about his life with the Indians, which were translated into many languages. He was also strongly involved in the Polish-Indian Movement and promoted the culture of his native ancestors. This paper aims to present the life and work of Sat-Okh with regard to his mysterious identity. Recently, there has been some doubt whether Sat-Okh's biography is genuine. However, I would like to argue that Long Feather's phenomenon proves the fact that regardless of whether he was a true Shawnee or not, Sat-Okh chose to identify himself as Indian and consistently presented himself as one. He taught Poles about Indian traditions and gained a tremendous respect which has lasted until today.

Key words: Sat-Okh, identity, Indian heritage, Native Americans, Canada
\end{abstract}

1 https://orcid.org/0000-0003-0306-2752

Ateneum-Szkoła Wyższa w Gdańsku, Wydział Neofilologiczny

m.leszman@ateneum.edu.pl 
Streszczenie

Sat-Okh (Stanisław Supłatowicz, Długie Pióro) był pisarzem i popularyzatorem kultury Indian północnoamerykańskich w Polsce. Jego niewiarogodny życiorys skłania do kwestionowania tożsamości tego Polaka-Indianina. Urodził się ok. 1922 r. na terenie Kanandy jako syn Polki i wodza Indian i przez pierwsze lata życia wychowywał się w plemieniu Szaunisów. Do Polski przybył wraz z matką po pierwszej wojnie światowej, ale do końca życia identyfikował się jako rdzenny Amerykanin. Podczas drugiej wojny światowej uciekł z transportu do Oświęcimia, po czym wstąpił do AK. Po wojnie stał się sławnym pisarzem publikacji o życiu Indian, a jego książki były tłumaczone na wiele języków. Sat-Okh był bardzo związany z Polskim Stowarzyszeniem Przyjaciół Indian i angażował się w promowanie kultury swoich przodków. Poniższy artykuł ma na celu zaprezentowanie postaci Sat-Okh'a w odniesieniu do jego tajemniczej tożsamości. Pomimo nieścisłości w biografii Supłatowicza, niniejsza publikacja przedstawia Sat-Okh'a jako człowieka, który stworzył własny wizerunek i konsekwentnie prezentował siebie jako Indianina. Sat-Okh to Indianin z wyboru, który propagował kulturę kanadyjskich przodków ciesząc się wielkim szacunkiem wśród polskiego społeczeństwa aż do śmierci w 2003 roku.

Słowa kluczowe: Sat-Okh, tożsamość, dziedzictwo Indian, rdzenni Amerykanie, Kanada

\section{Introduction}

I would like to tell you a story of Sat-Okh or Long Feather or Stanisław Supłatowicz. He is believed to be born on $15^{\text {th }}$ April 1920 or 1925 in Canada of a white mother, Stanisława Supłatowicz and an Indian father, who was member of the Shaunee tribe.

Who was this incredible man who became so popular in Poland at the time when Poles knew very little about the Native American people and their viewpoint of the Indian heritage was mostly based on the books by Karl May or James Fenimore Cooper?

The answer to this question may be more challenging than one would assume, since Sat-Okh's biography could reflect lives of several people, as it was so full of adventure and unbelievable twists of events.

Let me try to present the phenomenon of one man who became a legend in the post WW II Poland and who successfully created and re-created his own identity through writing books about Indians, by telling stories about his early life among the Shaunee tribe in TV programmes and by organising events which gathered young and old, for whom Sat-Okh became a role model. 


\section{Early Life and Literary Works}

In order to understand how Sat-Okh presented himself as a member of and Indian tribe, it is important to move back in time to the early 1900s to the small town of Radom in the south of Poland, where Sat-Okh's mother was married to Leon Supłatowicz, who was sent to Siberia for political reasons and soon after was followed by his wife, Stanisława. Because Leon died in Kireńsk, Stanisława was moved to Czukotka, but escaped to Alaska in 1916. The journey was so difficult that Stanisława almost lost her life and was found unconscious by Indians. The tribe took care after the woman and soon she married the village chief. He is the one that is believed to be Sat-Okh's father.

There are no official records that would prove the story told by either Sat-Okh or Stanisława, his mother, whose account is the only remaining testimony one can find in the archives. And yet, Sat-Okh's life story is the only version used in the biographical notes attached to his books about his life among the Indians. It is therefore difficult to assess whether the biographical elements in his stories are true events documented by the author himself, or perhaps they are mere creations of an imaginary reality. Sat-Okh gives a fairly detailed account of his childhood memories when he was a member of the Shawnee tribe in the North of Canada. These are his boyhood adventures, in which he describes Indian rituals, daily life activities and his own subjective observations on the life he is trying to capture on the pages of his books. One of the books which gives the most elaborate account of Sat-Okh's life in Canada is The Land of Salt Rocks, written in 1958. The events presented in this book took place before 1930, the period which includes the earliest years in the life of a small white boy, who was brought up as a Native American. Sat-Okh assures the reader that the story is not an imaginary account, but the real events recalled by the author himself. At the time of writing the book, the author claims that some of the characters are still alive, including his father, who is still the chief, however Sat-Okh's brother, Tanto is dead, as he was killed by white people. In the introductory note, he confesses that Poland became his new homeland, but he wanted to share the experience of his first one. Therefore, he decided to write about the difficult life of the Indians and hopes that thanks to the book, one would better understand their life, dreams and love for the forest, their fight for freedom, which they have very little, and which they really need so much.

What makes the literature written by Sat-Okh unique among other writers who undertake the subject of Indians, is the fact that the narrator 
experiences the events himself. Before Sat-Okh the Polish reader was used to stories which were fictional (such as Cooper or May). Therefore, if one assumes that Sat-Okh really grew up with the Indians, his stories might be the first accounts told by someone who truly knows the subject he is writing about. Sat-Okh gives an account of his early childhood and adolescence. The narrative voice is subjective and is not free from a polarised picture of the relations between the Native Americans and the white man. One can observe a certain degree of dichotomy in the construction of Sat-Okh's identity. He claims to be both: a white man and an Indian, the fact which results in an internal conflict, as the white component was considered undesired (Skotnicka, 70). One of the critics who analyses Sat-Okh's works, claims that the idea present in his books shows a character of a noble man, who is placed above the racial divisions. It is presented as something beautiful and eternal, perhaps serving as a remedy for the internal indecision. This idea is verbalised by one of the characters in The Land of Salt Rocks. The young protagonist's friend, who understands his internal conflict says at some point: „There is one human goodness and one human evil, despite various skin colours" (Skotnicka 70).

The Land of Salt Rocks used to be a position on my compulsory reading list in primary school. Published in 1958 the book brought Sat-Okh immediate fame and so far has been published eight times. The book turns out to be very popular and besides the autobiographical accounts, it is full of meditative passages on the Indian faith, rituals, social system, as well as poetic descriptions of the North Canadian nature. Sat-Okh maintains that he was writing from the insight of his own spiritual experience, describing the world to which he belonged. Because he was so strongly missing the Canadian forest, he decided to write, and to share these memories with other people in Poland. He says:

I want young readers to get familiar with the Native Americans' way of life, their beliefs, their worries, their affections. I want to show Native Americans from my own experience. I'm showing Native American spiritually, inwardly. I'm showing how they relate themselves to the surroundings, their religious beliefs, their history and legends. These are my books which are true regarding the Native Americans' subject; not some kind of fantasy. (Warrior by Birth)

At the rise of his popularity, Sat-Okh was a frequent guest in many TV programmes for children, where he would tell fascinating stories about his life as an Indian. He also appeared in various documentaries and talk shows, which made him a sort of celebrity at the time. But before he became a writer and a propagator of the Indian culture, Sat-Okh's life story proved to have many incredible twists yet again. 
According to his mother's testimony, at some point of their life with the Indians, two foreigners were found in the Canadian forest, one of whom spoke Polish. He told Stanisława that there is a new port being built in Gdynia, and that Poland in now free from the Tzar's regime. Stanisława started to miss her homeland and soon decided to set off on a long journey to visit home. Because she was supposed to return, her husband allowed her to take the youngest child, Long Feather with her to Poland. That is how they both arrived back to Radom. Unfortunately, the bliss of freedom did not last for long and with the WW II came the repressions. Already then, Sat-Okh was not believed to be of the „pure blood”, so he was put to prison and soon ended up in the transport to Auschwitz. Due to his extraordinary skills and incredible fitness, he miraculously escaped and ran into the forest, where he was found by the soldiers of the Home Army. Sat-Okh received his pseudonym „Kozak” and remained with the Army until the end of the war. There are several terstimonies left, in which his fellow soldiers remember Sat-Okh as someone special. They believed he possessed some skills that neither of them had. Apparently, he would be able to sneak like a cat and wander unnoticed by anyone, or walk backwards in order to leave misleading traces. This must be the time when the legend began to live its own life and since then Sat-Okh was slowly becoming an Indian.

\section{Becoming an Indian}

After the war, Sat-Okh spent some time in prison for his membership in the Home Army and after being released, he moved to the North of Poland, to Gdańsk, where he got employed at the ships and lived there until the end of his life in 2003. To this day, there are people who remember Sat-Okh's extraordinary attire and for many that was enough to truly believe in his Native American background. I have interviewed his neighbour, who remembers Sat-Okh as a local curiosity. He would often walk down the streets of the Old City wearing clothes which ordinary people would never wear, the clothes he would make himself and which made him look like an Indian. Until the end of his life Sat-Okh was wearing long hair, which was part of the whole image. But the real transformation would always take place during the events organized for young people, during which they have a chance te learn how to produce Indian jewellery, made their own clothes and shoes, build a teepee. They lived at camps and reenact the Indian village life. Whole families participated in such events, which became very popular. One has to 
keep in mind the fact that the communist Poland offered very little space for such activities, and in the face of that Sat-Okh's endeavours became a phenomenon of its own.

Personal accounts of such events and of Sat-Okh himself are rather sentimental and the descriptions of the atmosphere is often pastoral or even mythical. One of the participants (Marek Nowocień, Gazeta Biskupska) remembers Sat-Okh as he „would be the first to get up in the morning and take a swim in the lake, jump into the water from trees, win sports competitions (...) and was the best at throwing the lasso." (Nowocień, 6). Likewise, people who remember getting gifts from Sat-Okh claim that the condition was to let the object live, be displayed, shown to other people. Such an image seems idealized. According to members of the Indian Association, Sat-Okh (whom they called „Grandpa”) functioned a s a role-model to many young people at the time.

Sat-Okh's activities connected with the Indian life were not limited only to the domestic events and reinactment camps organized in Poland. After he moved to Gdańsk and got a job as a sailor, Sat-Okh took a chance to return to Canada on a cruise vessel „Batory”, where he worked as a sailor. In the 1960s Sat-Okh would return to Montreal several times and successfully established contact with the Canadian Indians and became friends with several of them. He visited the Mohawk reservation camp, known then as Caughnawaga. In the documentary about his life, Sat-Okh admits that his first cruise to Montreal was like coming back home, where he was received by the local chief Poking Fire. In fact, Poking Fire was more of a showman, who organized tourist events which welcomed people from all over the world. The reservation also invited the crew of the Polish ship "Batory”. It is in that place where Sat-Okh is photographed with a woman, whom he introduced as his sister he reunited in 1965. On the same occasion Sat-Okh recorded greetings for his father who remained in the secluded Shawnee village at the Mackenzie river in the Northwest Territories in Canada, somewhere in the tundra between the Great Slave Lake and the Great Bear Lake. Nobody knows whether his father actually received the recording.

In the documentary about Sat-Okh's life, entitled Warrior by Birth (Wojownik $z$ urodzenia), several Native Americans from Canada remember Sat-Okh as an extraordinary man, whose life, though difficult, proves his strength and urge to keep his Indian heritage alive. Richard Ground, member of the Black Feet tribe says: „Sat-Okh is our father in the sense of respect we give to our elderly people and to native people. To us he doesn't look like a white person, because he isn't. He looks like a Native American, because he is." This statement seems to suggest the belief in Sat-Okh's identity in the 
sense of his own conscious choice to be a Native American. To those, who believe Sat-Okh to be Native American, he will resemble one physically despite the controversy about his true ancestry.

Sat-Okh's fellow soldiers from the Home Army remember his incredible skills which came immensely helpful during the partisan life in the forest. Here is one of the testimonies quoted in the documentary:

He was a very handsome, young man who moved like a cat. Literally, he walked like a cat. He was a man of few words, but very resourceful in everyday life. (...) Sat-Okh was a man like every one of us living in the forest, but still different in some way. Why? He could move around noiselessly. (...) He had such a kind of springy walk. He moved around the forest so naturally like he was born there, like, let's say, the forest was his kingdom. (...) He could eat something, which we would never consider as food.” When it comes to military duty, „he was brave and was used for special assignments. (...) Sat has belonged to those people who knew horses inside out. He was even openly joking many times that he has learned to mount a horse well before he has learned to walk. ("Sat-Okh, Wojownik z urodzenia", movie subtitles - translation: Janusz Kozłowski and Klaudiusz Jankowski)

Himself, Sat-Okh says the following about his service in the Home Army:

I could find out traps, I was sent for reconnaissance, I was a scout, and I was showing the safe pathways to my party. (...) I'm proud that being a Native American by blood I was able to represent my nation; a nation which for all of its existence has been fighting for its freedom as I was fighting for the freedom of the Polish people, for my mother's native country. And the fact that I have earned a respect of younger generation of Polish people is not that I'm half-Pole but I'm a Native American who was fighting for Poland, being involved in the underground movement. ("Sat-Okh, Wojownik z urodzenia", movie subtitles - translation: Janusz Kozłowski and Klaudiusz Jankowski)

Such statements and the story behind them make Sat-Okh a hero in the eyes of both the young generation of Poles who are interested in the Indian heritage, as well as the Native Americans living in North America, who value and respect Sat-Okh and consider him as one of them. He is perceived as a warrior, the term which is often used by the people who knew Sat-Okh, someone who lived a life of values he was ready to fight for. 


\section{Controversy}

In 2017, Dariusz Rosiak, a Polish journalist published a book about Sat-Okh, entitled White and Red. The Mystery of Sat-Okh, in which he undermines the facts regarding Sat-Okh's identity. The author's research proves many inconsistencies related to his place of birth or even the identity of Sat's father. Rosiak claims that a Metis such as Stanisław Supłatowicz could not have been white, and Sat-Okh was. He also points out that Sat-Okh was nothing more but an imposter, whose biography cannot be proved in any of the archives. What is more, it is implied that Sat-Okh was using ghostwriters and the stories were a medley of various North American Indian stories, fragments of which SatOkh connected together.

\section{The Living Legend}

We love legends. We want to believe in romantic stories, especially if they match certain social expectations. Sat-Okh's life story was perfect for its times. People in the communist Poland were thirsty for the exotic touch to their gloomy reality and Sat-Okh appeared ideal to meet such expectations. Interestingly enough, the socialist regime never really censored Sat-Okh's works. He was well-received in Russia, and his works were widely read across Poland's eastern borders. He travelled to the Soviet Union and published some of his works in collaboration with Russian writers as well.

Sat-Okh's incredible career is well documented and there are many witnesses, who still remember Supłatowicz. His Indian identity is still taken for granted. In Gdańsk there is even a tram which is named after Long Feather. The „Polish Indian” was known abroad, and his works were translated to different languages. A small Kashubian town, Tuchola holds a local museum devoted to North American Indians, and is named after Sat-Okh. Likewise, a ten-kilometre fragment of a Polish high way is named after Sat-Okh: „Indiańska Droga Sat-Okh'a” (Sat-Okh's Indian Road).

Sat-Okh's literary works are used as therapeutical legends read to children, according to Marcin Lutomirski, who analyses Biały Mustang in the context of its pedagogical value in educating young learners.

Even popular journalism took the case of Stanisław Supłatowicz under its wing and produced a short documentary published on youtube.com, in the Internet based series entitled „Enigma”. The documentary presents Sat-Okh's life story, yet the biographical facts do not add any new insight 
to the story which Stanisław Supłatowicz told about his own life.

\section{Conclusions}

It is probably impossible to settle the dispute concerning the factual events around Sat-Okh's life story. Sat-Okh's birth certificate never existed, and he himself claimed that the Indians measured time differently than the Europeans. Sat's mother, Stanisława's testimony is also full of gaps, but she was an elderly woman, and her memory could have been faulty. What is more important and more interesting however, is the question how and why Stanisław Supłatowicz decided to become Sat-Okh and was so consistent about this identity until his death in 2003.

Sat-Okh's life is a story of a Polish national hero and a Native American. In his stories he says what it means to be Polish, how to deal with the war suffering, how to connect identities, and how to love other people and share the experience of loss.

\section{REFERENCES}

Jankowski, K. (2007). Wojownik z urodzenia [film dokumentalny], scen., reż., zdjęcia: Klaudiusz Jankowski. TVP, 2007.

Krępulec, K. \& Supłatowicz, S. (2004). Niezwykła biografia Sat-Okha, czyli jak się zostaje legendą [Praca magisterska napisana w zakładzie Historii Najnowszej pod kierunkiem prof. dr. hab. Zbigniewa Zaporowskiego]. Lublin: Uniwersytet Marii Curie-Skłodowskiej. Dostęp: www.indianie.eco.pl/litera/sat-okh1.html

Lutomirski, M. (2012). Baśnie indiańskie Sat-Okha i ich rola w wychowaniu [szkic]. W: Kawalla, S., Lewandowska-Tarasiuk, E. \& Sienkiewicz, J. W. (red. nauk.) Baśń $w$ terapii $i$ wychowaniu. Warszawa: TRIO. s. 101-110.

Pogodna Wiewiórka (2003). Wspomnienia o Stanisławie Supłatowiczu, czyli Sat-Okh jakiego znali. Gazeta Biskupińska, 72/VIII (25.09.2003), s. 6. Dostęp online: http://www.indianie.eco.pl/r2003/biskupin2003/gb6.pdf

Rosiak, D. (2017). Biało-czerwony. Tajemnica Sat-Okha. Wołowiec: Wydawnictwo Czarne.

Sat-Okh. (1959). Biały Mustang. Warszawa: Nasza Księgarnia.

Sat-Okh. (1958). Ziemia słonych skał. Warszawa: Czytelnik.

Skotnicka, G. (2000). Polski Indianin i jego twórczość: studium wybranych problemów [rozprawa] Gdański Rocznik Kulturalny, 19(2000), s. 54-71.

Świerszcz, L. (2014). Zabijał Niemców dla Polski: nieprawdopodobna historia: Enigma [film dokumentalny] (8 min. 53 sek.). Produkcja i zdjęcia: Leszek Świerszcz Telewizja Internetowa WP.TV. Opublikowano 17.11.2014. Dostęp online: www.youtube.com/watch?v=wN20higwkVE 
